\title{
Механизм возникновения ошибок в оптическом грозотросе при ударе молнии
}

\author{
$\underline{\text { В.А. Конышев }}^{1,2, *}$, О.Е. Наний ${ }^{1,3}$, А.Г. Новиков ${ }^{1}$, В.Н. Трещиков ${ }^{1,4}$, Р.Р. Убайдуллаев ${ }^{1}$ \\ ${ }^{1} O O O$ «T8 HTЦ» \\ ${ }^{2}$ Институт истории естествознания и техники им. С.И. Вавилова РАН \\ ${ }^{3}$ МГУ им. М. В. Ломоносова, Физический факультет \\ ${ }^{4}$ Институт радиотехники и электроники им. В. А. Котельникова РАН \\ "E-mail: konyshev@t8.ru
}

DOI:10.31868/RFL2018.216-217

Гигантский рост трафика в современную эпоху заставляет переходить при строительстве протяженных волоконно-оптических линий связи на плотное волновое мультиплексирование (DWDM) с межканальным расстоянием 50 ГГц, а при формировании самих каналов использовать когерентную передачу. Так когерентные транспондеры DP-QPSK 100G (скорость передачи данных в канале 100 Гбит/с) масштабно используются в современных проектах. В последние два года также стали предлагаться решения с использованием когерентных транспондеров на большие канальные скорости (200 Гбит/с и более).

Однако, такие когерентные системы, как оказалось могут иметь в процессе эксплуатации недостатки. При определенных условия, когда воздушная ВОЛС с использованием оптического грозотроса оказывается в зоне грозового фронта, в канале связи могут возникать ошибки в моменты попадания молний в оптический грозозащитный трос [1,2]. Разряд молнии, которая попадает в оптический грозотрос, приводит к ошибкам на линии. Более ранние стандарты передачи, базирующиеся в частности на формате модуляции ООК, не подвержены такому воздействию молний.

На сегодняшний день главным эффектом, приводящим к ошибкам во время гроз в когерентной линии связи, содержащей в качестве кабельной инфраструктуры воздушные ВОЛС, является эффект Фарадея, заключающийся во вращении плоскости поляризации линейно поляризованного излучения, проходящего через прозрачную изотропную среду (в нашем случае через волокно) под воздействием индуцированного сильного магнитного поля. Угол вращения состояния поляризации на выходе $\theta$ определяется по формуле [3]:

$$
\theta=V B L,
$$

где $V$ - постоянная Верде, для волокна $V=0,53 \mathrm{rad} / \mathrm{T} / \mathrm{m} ; B-$ индукция магнитного поля (T, тесла); $L$ - длин участка волокна, м.

Продольное магнитное поле формируется вследствие винтового тока молнии, идущего по скрученным алюминиевым жилам грозотроса. Имеется фаза быстрого роста поля ( 10 мкс) затем медленная фазы спадания поля. Оценка величины такого поля при известном значении шага скрутки жил не составляет труда. В тоже время вопрос количественной оценки влияния этого поля на передаваемый по волокну в грозотросе сигнал на сегодня до конца не изучен.

Для количественной оценки эффекта Фарадея в волокне была собрана установка (см. рисунок 1). Непрерывный оптический сигнал на длине волны $\lambda=1550$ нм от лазера поступал через поляризатор на катушку с одномодовым стандартным волокном, длиной 50 км, затем пройдя по катушке, поступал в поляриметр. Внутри катушки с волокном можно было изменять продольное магнитное путем, изменяя ток, проходящий через соленоид, намотанный вокруг 
катушки (число витков $N=30$ ), от нуля до максимального значения $I_{\max }=40 \mathrm{~A}$.

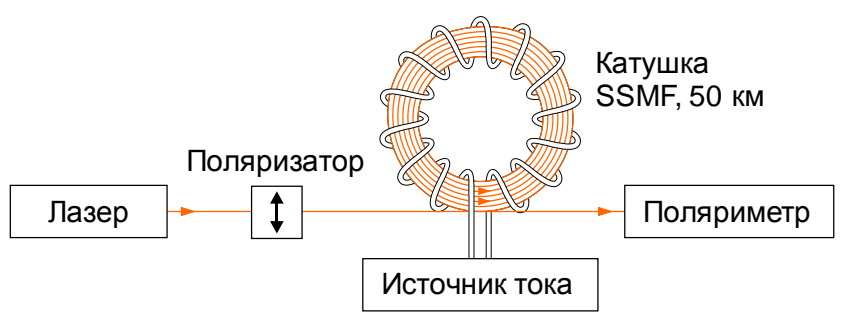

Рис.1. Экспериментальная установка.

После катушки с волокном был установлен поляриметр, определяющий угол вращения состояния поляризации PSP. В отсутствии поля PSP плавно изменяется и со временем. Задача эксперимента определять, как изменяется угол между выходным состоянием поляризации в отсутствие магнитного поля и сразу же после его включения от величины поля.

В процессе проведенных экспериментов обнаружено сильное подавление эффекта Фарадея, не выполнялась формула (1). Для объяснения этого была построена теория, основанная на случайном изменении главных состояний поляризации в волокне по мере распространения сигнала. С помощью этой теории и моделирования случайных процессов получена модификация формулы (1):

$$
\langle\theta\rangle=\frac{1}{5} V B L_{B} \sqrt{\frac{L}{L_{c}}},\left(L \gg L_{B}, L_{C}\right),
$$

здесь $\langle\theta\rangle$ - усредненный угол вращения состояния поляризации на выходе, (rad); $L_{B}$ - длин биений в волокне, м; $L_{C}-$ корреляционная длин в волокне, м. Формула (2) показала значительно лучше согласие с экспериментом, и объяснила подавление эффекта Фарадея в протяженном участке волокна.

Сделан вывод о том, что шибки на линии возникают именно в следствие локального (через грозотрос) воздействия молнии на участок волокна и создание на этом участке магнитного поля, характерная протяженность участка 100-200 м. Модель, предложенная в работе [4], допускающая удаленное влияние молний (не обязательно прямое попадание в оптический грозотрос) на ошибки в линии оказалась несостоятельной.

\section{Литература}

[1] D.S. Waddy et al., IEEE Photonics Technology Letters. 13(9): p. 1035-1037 (2001)

[2] S.M. Pietralunga et al., IEEE photonics technology letters. 16(11): p. $2583-2585$ (2004)

[3] Mansuripur, M., Field, Force, Energy and Momentum in Classical Electrodynamics (Revised Edition). 2017: Bentham Science Publishers

[4] P.M. Krummrich, D. Ronnenberg et al., Optics express, 24(11) : p. 12442-12457 (2016) 